\title{
Cultivating Agents of Social Media Literacy through Service Learning
}

\author{
V. Sukmayadi \\ Communications Department, Universitas Pendidikan Indonesia \\ Bandung, INDONESIA \\ vsukmayadi@upi.edu
}

\begin{abstract}
Today's learning is focused on preparing students with characters and skills needed to pursuit their career and to succeed in their future. Beyond those skills, there are various supporting proficiencies that are significant in preparing for the "wild" world out there. Among those new proficiencies is social media literacy, a set of skills that one's should have in order to communicate appropriately, responsibly, and to evaluate conversations critically within the realm of socially- based technologies. Regarding this, the paper described of how media and social media education can be designed as a method to prepare and engage undergraduate students to be agents of social media literacy. This paper focuses on a media literacy course that teaches how media users receive and interact with various types of media. The students of this course learned various topics for the first half of the even semester of 2015 , then by the second half of the semester the course sent them to conduct a community service learning. The students were placed into teams and sent to share what they have already learned on campus to students in middle and high schools programs in rural areas. A participant action research (PAR) is used to evaluate, upgrade and finally improve the course for future reference.
\end{abstract}

Keywords - media literacy, social media, service learning.

\section{INTRODUCTION}

Today, Social media has become a necessity for most people. Nowadays the Internet and social media are not just a fad, but they have been transformed into a social need. $40 \%$ of the world population have an Internet connection (Internet Live Stats, 2015). While In Indonesia, the number of Internet users increased rapidly to $30 \%$ of the total population or about 73 million users (APJII, 2014). A survey conducted APJII also showed that social media activities are the most frequently performed activities on the Internet and the average hours of logging in have reach more than five hours per day. Additionally the average user of social media are dominated by teens (13-18 years) and young adults (18-29 years) (Bennett, 2013).

There were no historical notes on how sharing information or simply posting various status in social media can be so addictive. However, the science behind the potentially addictive feeling while using social media was analyzed by Paul J. Zak (in Rudin, 2010). The result of his study shows that 10 minutes of logging in to Facebook and Twitter can produce oxytocin hormone from our brain that can release feelings of affection and contentment. Besides, engaging in a digital interaction releases adrenalin. The hormone becomes the main reason of why people get really excited when they see a notification by someone else on their social media posting.

Concerning the facts above, social media can not be underestimated and a new literacy is needed in order to cope with the phenomenon.

\section{SOCIAL MEDIA LITERACY}

In the beginning of the web 2.0 era, literacy means the capability to use the internet based tools. However, along with the vast advancement of technology, Knowing how to use social media such as Twitter, Facebook or Line is not demonstrating social media literacy. Knowing how to operate a social media or internet can be defined as digitally literate but not the same as social media literacy.

Social media literacy is the knowledge, skills, attitudes and self-efficacy of individuals to (appropriately) use social media applications and to analyze, evaluate, share and create social media content (EMSOC, 2015). In other words, media literacy is having the proficiency to communicate appropriately, responsibly, and to evaluate conversations critically within the realm of socially-based technologies.

This aptitude need to be embedded to social media users. In Indonesia media and social media literacy are not part of the primary and secondary schools' curriculum. The subject is only introduced in higher education and mostly in communication, information and technology based departments. Moreover, unlike broadcasting media, the internet and social media in Indonesia do not have a commission and a very comprehensive regulations to keep a check on the on line content traffic.

Given all the opportunities and threats of social media, the author introduces the concept of social media literacy agents as a part of media literacy subjects taught in the author's institution (UPI Communications department). 


\section{Cultivating Social Media Literacy Agents}

The main idea of this course is to prepare students knowledge and awareness toward social media literacy. The course structure in not merely in form of a traditional lecture about media literacy but it emphasizes more on "products" from what the students have learned that can be shared with the communities.

There are two steps in embbeding social media literacy values to the students. First is the forging of their knowledge and mental awareness toward digital technology and social media. Secondly, The students are specially prepared to be immersed with the community to share their knowledge.

The first step was conducted by introducing six concepts of social media literacy based on the course teaching outline (adapted from Rachmiatie, 2014; Tillman, 2010). The following are the six concepts that have been embedded to the students:

1. Ability to technically utilized social media knowing how to operate social media applications.

2. All media messages are constructed - The media do not simply reflect external reality. Rather, they present carefully crafted constructions that reflect many decisions and are the result of many determining factors (cited from http//:medialit. org, 2015)

3. Diverge audience means different understanding and acceptance of the same Message - One's must aware about the diversity of our audience and how our online content can easily travel beyond our intended audiences, even if we believe they are one-on-one, private communications.

4. Critical thinking content consumption - In the absence of traditional media fact- checking or with the presence of media agendas, always critically analyze content that is shared and published by others - whether from citizens, brands or governments. Consider the content before you share.

5. Responsible "posts" - Use common sense when communicating online since conversations become content that are frequently indexed, difficult to delete if replicated, and thus forever searchable

6. Impression management - Establish different social accounts or blogs to manage different personas and topics, or between professional and personal interests, and share them respectively with your targeted audiences.

The above concepts are introduced to the students and discuss them for the first half of the semester. The objectives of the lecture and the training are to make the students aware that While the media landscape has radically changed, the criteria for evaluating content has not. The lens of criticality that holds media creators and distributers responsible should be applied. to everyone ( in this sense teens and young adults user since they are the most frequently users).

\section{SERVICE LEARNING AS A SHARING MEDIA}

The second step of this course is to involved the students in developing an education program regarding social media literacy. At the second hal of the semester, the students need to design a non-directive couseling to the community, particularly teenagers in the community.

The program was conducted in form of service learning. Service learning is a process of involving students in community service activities combined with facilitated means for applying the experience to their academic and personal development. It is a form of experiential education aimed at enhancing and enriching student learning in course material (uncsfu, 2015). The service learning can be very beneficial for the community since they have lack of socialization about social media literacy. In addition, service learning can serve as a more practical evaluation in rating the students understanding of the course and give a valuable civic-engagement experience for the students.

In the media literacy course, the students were assigned to design a project-based service activities for students aged 13-17 years in suburb areas (students may choose the location between $10-80 \mathrm{~km}$ from the main campus).

In designing the social media literacy projects, the students were encouraged to create an innovative method of delivery. Thereby, instead of having a classic lecture (one or groups of students talking in a classroom and in front of the audience), the students shared their knowledge as a tutor in small groups. Each group consists of two tutors and 5-6 high school or junior high school students. By having small groups, the participants and the tutors can engage in a closer and more open discussion.

This activity gives the participant a mutual learning experience. All participants are engaged in relationships not only of reciprocity, in which all contribute and all benefit, but of mutual learning, growth, and change.

This kind of program gives interdependent learning outcomes and emphasizes the careful use of critical reflection and thoughtfully designed integration of service experiences with course content in order to generate learning and growth (Labhrain, 2007).

The outcomes of the program was satisfactory, all of the participants considered that the topic was very insightful. The participants perceived positively toward the method of delivery. Since there were less age gap between the tutors and participants, they consider the method was hit the mark.

\section{CONCLUSION}

Media and social media literacy will provide the ability for internet users to shape the media through digital and social media. Due to its complexity, social media literacy should be introduced and socialized to all digital users. Social media literacy teaching can guide students how to harness the power of social media in a positive manner. Finally, by having social media literacy agents and service learning the message can serve as an alternative solution while waiting for media literacy to be occured in Indonesia education curriculum. It is critical that we guide our students 
how to be a wise digital citizens and how to habituate a positive digital behaviour.

\section{REFERENCES}

[1] Bennet, S. (2013). Social Times. Retrieved from Adweek:http://www.adweek.com/socialtimes/social- networkuser-demographics/489992

[2] EMSOC. (2015, 10 8). university of Gent. Retrieved from university of Gent: http://www.ugent.be/ps/communicatiewetenschappe n/en/research/mict/past projects/2014/emsoc

[3] Internet Live Stats. (2015, August 27). Retrieved from http://www.internetlivestats.com/internet-users/

[4] LABHRAINN, L. M. (2007). Higher Education and Civic Engagement: Interntional Perspectives. Burlington: Ashgate Publishing Company.

[5] Rachmiatie, A. (2014). Garis Besar Program Pengajaran: Literasi Media. Bandung: Departemen Ilmu Komunikasi UPI.

[6] Rudin, A. (2010). The Science Behind Feeling Good While Social Networking. Huffington Post.

[7] Tillman, K. (2010). Do Media Literacy, Digital Literacy, \& Social Media Literacy Intersect? Edelman Digital.

[8] APJII (2014). Profil Pengguna Internet Indonesia. Jakarta: Asosiasi Penyelenggara Jasa Internet Indonesia.

[9] Fayetteville State University (2015). Civic Engagement Program. Retrieved from http://www.uncfsu.edu/civic-engagement/servicelearning/definition-of-service-learnin. 